\title{
Sieyès and Republican Liberty
}

\author{
Adam Lindsay \\ School of Politics and International Relations \\ University of Nottingham \\ NG7 2RD \\ adam.lindsay3@nottingham.ac.uk
}

\begin{abstract}
:
In On the People's Terms, Philip Pettit incorporates the Sieyèsian notion of constituent power into his constitutional theory of non-domination. In this paper, I argue that Emmanuel Sieyès's understanding of liberty precludes such an appropriation. While a republican, his conceptualisation of liberty in the face of commercial society stood apart from theories of civic vigilance, preferring instead to disentangle individuals from politics and maximise what he understood to be their non-political freedoms. Sieyès saw that liberty was heightened through relations of representation and commercial dependency. This conception of liberty was pivotal to the identity of the nation, and so allowed Sieyès to assess forms of collective injustice committed by the French nobility. It also provided the normative foundation to his theory of constituent power. For Sieyès, constituent power guarded against legislative excess in a decidedly minimal sense, intending instead to separate citizens from the political sphere so they were not burdened with ongoing participation or public vigilance.
\end{abstract}

Key Words:

Liberty, domination, dependency, representation, republicanism, constituent power 


\section{INTRODUCTION}

Neo-republicans associate liberty with non-domination (Pettit 1997; Skinner 1998). ${ }^{1}$ For Philip Pettit, domination arises when one party has the capacity to interfere on an arbitrary basis, and with impunity, with the choices of another (Pettit 1997:22). In his most recent work on the subject, On the People's Terms, Pettit has sought to account for the democratic institutions associated with this understanding of liberty. Here, he identifies republican liberty with the Sieyèsian notion of constituent power (Pettit 2012:285-292). In this paper, I argue that Sieyès's understanding of liberty precludes a straightforward incorporation of constituent power into a constitutional theory of nondomination. While a republican, Sieyès was an idiosyncratic one; his conceptualisation of liberty in the face of commercial society stood apart from theories of civic vigilance, preferring instead to disentangle individuals from politics and maximise what he took to be their non-political freedoms.

Pettit's republican constitutionalism, while analytical in scope, is grounded and enriched by a highly stylised historical excavation of republicanism (1997:17-51; 2012:5-25; 2013). ${ }^{2}$ Pettit celebrates what he labels the ItalianAtlantic tradition, inherited from classical Rome, which emphasised the freedom from the domination of a master. Rediscovered in Renaissance Italy, it sparked the English Civil War and enflamed the American Revolution (Pettit 2012:2). Liberty was secured through the constitutional constraints of the mixed constitution, and an understanding of civic virtue to vigilantly track public policy. Pettit contrasts the Italian-Atlantic tradition with a 'continental' variant of republicanism rooted in the Rousseauvian transformations of the $18^{\text {th }}$ century. While this 'continental' tradition maintained the ideal of non-domination, it did so by abandoning the mixed constitution in favour of a popular absolutism through which the free person was equated with a politically active participant (Pettit 2012:18; 2013). Pettit's history of republicanism has inevitably found itself a target for criticism (McCormick 2003; Nelson 2004; Ghosh 2008). This paper 
extends this perspective through a reading of the republicanism of Emmanuel Sieyès, who further unsettles Pettit's dualist history of republicanism.

I do so by excavating Sieyès's own formulation of republican liberty. After situating Pettit's interpretation of Sieyès within the existing scholarship, I argue that that Sieyès developed an account of liberty that sought to challenge a brand of aristocratic French republicanism indebted to the English Commonwealth tradition. The thése nobiliaire entrenched the power and status of the nobility under the guise of protection against monarchical absolutism. Against this, Sieyès developed an argument for liberty that celebrated the dependency generated by commercial society. His proposal hung on a distinction between liberty of independence and liberty of empowerment. This provided a normative justification for the commercial division of labour and for a practice of social representation and sought to sharpen the benefits one received when dependent on others. This interpretation is developed in the second section. In the third section, I show how his presentation of liberty patterned his revolutionary constitutional theory, notably, the normative ordering of the nation. Here, Sieyès identified a set of interactions between the symbiotic dependency within the Third Estate, the parasitic dependency of the noble order on the nation, and the feudal domination of the noble order over the rural peasantry. While guarding against the most pernicious forms of domination enacted by the remnants of feudalism, Sieyès prioritised the gains to liberty produced by commercial society, improving the efficiency, quality and choice presented to individuals. These distinctions provided one set of normative foundations of his version of republican constitutionalism.

In the final section, I argue that this contrasts in a critical way with Pettit's republican constitutionalism. While Pettit does recognise the importance of trust and mutual dependence to public life (1997:262-270), he differs from Sieyès with respect to the normative ordering of dependence within their respective conceptions of liberty. This had political implications: the centrality Sieyès ascribes to liberty of empowerment alters the grounds on which political 
representation is operationalised, tempering the mechanism of public responsiveness that is key to Pettit's vigilant tracking of trust. If constituent power was to guard against legislative excess, it did so in a decidedly minimal sense: for Sieyès, representation and constituent power were each mechanisms to separate citizens from the political sphere so they were not burdened with ongoing participation or public vigilance. This should be seen as a problem for any attempt to incorporate Sieyès into a constitutionalism of non-domination.

\section{SIEYÈS AND REPUBLICAN LIBERTY}

The place of liberty in the constitutional thought of the Abbe Sieyès is routinely marginalised. This is, in part, because much effort has been invested in tracing the intellectual ancestry of his contributions to the theory of sovereignty, often with the broader aim of identifying the intellectual origins of the French Revolution. This can be seen in the resurgence of Sieyès among interwar legal theorists, namely Raymond Carré de Malberg (1922) and Carl Schmitt (2008) for whom the Sieyésian nation took on the gloss of a Rousseauvian general will. Arendt, too, succumbed to this reading when, in The Origins of Totalitarianism (1967:231), she associated the constituent power of the nation with a 'pseudomystical aura of lawless arbitrariness' that eroded the freedom of the people. For these interpreters, constituent power was understood to be interchangeable with unbridled popular sovereignty, and for Hannah Arendt the Terror was evidence of this interpretation. ${ }^{3}$

This presentation of Sieyès has come under scrutiny by those who have emphasise the centrality of representation to Sieyès's constitutional theory (Baczko 1988; Baker 1990; Forsyth 1987; Sonenscher 2003). Istvan Hont's pathbreaking work, for instance, proposed that Sieyès's debt was to Thomas Hobbes, whose notion of union through artificial representation stood behind the Sieyèsian nation, laying the foundations for the modern state-form (Hont 2005:486). Hont's intervention appropriately restored individual liberty to Sieyèsian constitutionalism against the impositions of an exaggerated 
decisionism. Others have emphasised the liberal constitutionalism that followed from this, whereby the representative form of the constituent power served as a limit upon the authority of the constituted powers, thereby guaranteeing the rights of man. This stance remains common within the French literature where his distinctiveness from Rousseau has been long argued (Clavreul 1987; Guilhaumou 1997:18-23; Pasquino 1998; Tyrsenko 2000:29-31; Fauré 2008). However, while the importance of individual liberty is recognised, its composition is left undertheorised. It is a mistake to envisage Sieyès's understanding of liberty as something secondary to his styling of the nation. I argue that the two are profoundly connected, and that his reworking of republican liberty provides the normative anchor to his constitutionalism and his account of representation.

This is not to argue that his conception of liberty has been neglected wholesale. However, those that have elaborated his conception of liberty have subsumed him into orthodox republicanism, or early liberalism. Egon Zweig, now over a century ago, argued that his account of freedom was the key to understanding the anti-Rousseauvian dimension of Sieyès's thought. Zweig emphasised Sieyès's authorship of the Déclaration, presenting citizens as rights bearers for whom freedom met its limits only upon harming the freedom of others (Zweig 1909:127). ${ }^{5}$ This presentation collapses Sieyès into negative liberty in the Berlinian form of non-interference. Elsewhere, Pasquale Pasquino has alluded to the Sieyèsian roots of Benjamin Constant's distinction between ancient and modern liberty, contending that the individualism of modern liberty followed from Sieyès's representative government (Pasquino 1987:214-15; see also Guilhaumou 1997; Sewell 1994:101-2).

If these views emphasise Sieyès's liberalism, others present Sieyès's understanding of freedom in a more directly republican vein, for while liberty was understood in terms of individual freedom, it took the republican form of non-domination. As Rubinelli (2019.a:52) presents it, non-domination figured in Sieyès's constitutional theory as consent to the laws that are made. Rubinelli does 
appreciate that Sieyès's account of liberty is double-faced, consisting also of the freedom granted to individuals through the division of labour. She argues that constituent power was a constitutional device to reconcile this dualist understanding of liberty, in contrast to the dominium of sovereignty. While constituent power took the form of the authority of the people to constitute the state, consistent with the first component of liberty, this was to be executed by extraordinary representatives, consistent with the second component (Rubinelli 2019.a:53-54). I maintain that these modes of liberty were not complementary and compatible, but conflicting, and this required a trade-off. Sieyès subordinated the principle of non-domination to the gains of dependency, and this amends the normative ordering of the nation and shapes the character of Sieyesian republicanism.

This ordering is important: although Pettit's elaboration of Sieyès's place as a theorist of republican constitutionalism is brief, with no mention of liberty itself, ${ }^{6}$ he presents constituent power as easily reconcilable with the ideal of republican liberty. This entails a 'dual-aspect' model of democracy. In the first, 'constituent' aspect, the people appear as a plurality to determine the metaprinciples to guide lawmaking. In the second, constituted aspect, the people appear as a corporate entity within the bounds set out by the metaprinciples of the constitution. In this way, constituent power appears as a regulative principle to assess from critical distance the internal function of constitutional decisionmaking. As decision-making is guided by the norms devised by a plural constituent power, the authority of the constituted people is therefore nonsovereign, and non-dominating (Pettit 2012:290). Pace Pettit, I argue that under Sieyès's presentation of liberty, constituent power is not to be understood as a vigilant check upon a dominating legislature, but rather as means of disentangling citizens from the civic process. Antonio Negri (1999:218) has argued that this was a fall from grace, transforming a vibrant contestatory republicanism into a 'tortuous combination of representation and government'. However, Sieyès did not see the arguments at which he took aim as vibrant or 
contestatory. Rather, he saw it as a means of entrenching the power and status of the nobility. His matrix of liberty open channels for evaluating instances of collective injustice in this republican tradition.

\section{SIEYÈS ON FREEDOM AND DEPENDENCY}

It is tempting to assume that Sieyès was a 'conventional' theorist of republican liberty. In a note likely written during the Thermidorian Reaction, he wrote, 'no man has the right to dominate another. A free man is he who obeys his own will' (Sieyès 1999.c:474). ${ }^{7}$ Such assumption distorts the political landscape. The vocabulary of republicanism in the late $18^{\text {th }}$ century was both pervasive and deeply variegated (Philp 1998), a quality that Pettit's stylised opposition does not accommodate. This aspect is also lost among traditionalist accounts of French republicanism, who treat its development in isolation from broader republican currents across Europe (Nicolet 1982; Furet and Ozouf 1993). This is true neither of Sieyès nor the wider French republican tradition. Sieyès read English and had access to an extensive range of works of English Commonwealthmen, including Milton, Harrington, Shaftsbury, and Bolingbroke (Forsyth 1987:38-40). ${ }^{8}$ Moreover, recent work has demonstrated that the English Commonwealth vocabulary permeated France more deeply than was previously assumed (Jainchill 2008; Hammersley 2010).

One such example was Henri de Boulainvilliers, with whose work Sieyès was well acquainted. ${ }^{9}$ His aristocratic republicanism argued for a Frankish liberty, comprising an original condition of being 'perfectly equal and independent, both in general and as an individual', a 'precious liberty' that had been defended against Roman and barbarian invasion, and guarded by the noble order as the only legitimate government of the realm (Boulainvilliers 1727:2627). ${ }^{10}$ The ancient form of mixed government stood in contrast to the absolutism that had grown out of Roman rule, and Boulainvilliers called for the restoration of the former. This was the thèse nobiliaire, which adapted arguments from the English commonwealth tradition to the French context. One likely source of 
this argument was Lord Bolingbroke, a friend of Boulainvilliers who had championed the vocabulary of English liberty and communicated it through the gothic language of the ancient constitution in the pages of The Craftsman (Hammersley 2010:64).

These arguments had been developed in less aristocratic forms by individuals like Gabriel Bonnot de Mably in the mid- $18^{\text {th }}$ century, though they retained the appeal to ancient liberties threatened by corrupt magistrates and the emerging commercial society. ${ }^{11}$ Mably's Des Droit et Des Devoirs du Citoyen, organised as a dialogue between a Frenchman and an English Commonwealthman, keys us into these arguments. Through the mouthpiece of the Englishman Stanhope, Mably presented a commonwealthman's analysis of the British constitution coupled with a cautious suggestion for importation to France. For Stanhope, commerce 'infected' society with the vices of its neighbours (Mably 1972:9). This replaced civic virtue with private interests, the remedy for which was the vigilant guardianship of ancient liberty against the modern threat of commerce and the court.

Sieyès was familiar with these arguments of ancient Frankish liberty, and he dismissed them offhand in What is the Third Estate? (Sieyès 2003.c:99). Sieyès challenged this vocabulary, developing his own idiosyncratic language of republicanism more amenable to commercial society. Rather than being 'infected' by the vices of commercial exchange, or being preserved by an ancient order of nobles, Sieyès saw liberty as intimately connected with representation and enhanced by commerce. Identifying how commercial dependency enabled this was vital to a materially inclined assessment of instances of unfreedom.

Sieyès saw himself as a sociologist (Guilhaumou 2006). Liberty was not to be understood in the abstract, but as a manifestation of the material relations of society. These material relations were representative. This was clear even in his notebooks on metaphysics from the early 1770 s, where Sieyès drew attention to the relation between liberty and representation. A 'representative sensation' was the product of a plurality of sensations within a single sense organ: an image 
or a melody was a representative sensation. Sieyès's proof for one's existence lay in the experience of such representative sensations (Sieyès 1999.a:75). The body was composed of a plurality of organs each of which experience the world differently: one's feet can be cold, while their head is hot, and these representative sensations were to be mediated into a composite form. The immediate reception of representative sensations was passive, but the examination and deliberation of them by the will was an active endeavour. Individual liberty in its elementary form resided here (Sieyès 1999.a:81). The will was thrown into a relation of representation with the sense organs and was free to decide how it responded.

For Sieyès, there was no autonomous will freed from representation. Representation was not antithetical to freedom, despite the proclamations of his contemporaries. ${ }^{12}$ Rather, the will's freedom to decide was heightened because of representative relations. The sense organs distilled a plurality of sensations into a more readily interpreted representative sensation upon which the will could make a judgement. The will's capacity to make an effective judgement was aided by the work initially completed by the sense organs, and so to enact one's will was to take advantage of the assemblage of representative connections within the body. Society, for Sieyès, was an extension of this logic. Just as the human body consisted of a plurality of organs that aided the freedom of the will, so too was society composed of myriad representative organs that aided individual freedom. This was because as a member of society each individual was exposed to an ever-greater range of representative sensations (Sieyès 1999.a:77-78). In short, one's freedom was enhanced through their dependence on others in society.

The translation of this corporeal analogy into society was expressed clearest in his essay 'Of the Gains of Liberty in Society and in the Representative System'. He explained that the liberty proper to humans was a liberty within social relations. Those who assume liberty was possible in isolation mistook liberty for mere independence. As humans have needs, and as needs have given 
rise to society, Sieyès posited, independence alone was insufficient. Sieyès distinguished between two frameworks of liberty in society: liberty of independence, and liberty of empowerment [liberté de pouvoir]. Of the former, he considered a man free 'when he is not hindered by other men from exercising his will'. Sieyès intended this definition to accord with 'common usage', and this was to be understood in an expansive sense, accommodating both physical and psychological conditions of unfreedom (Sieyès 2014.b:145). More precisely, his definition corresponded to the ancient liberty of Frenchmen expressed in Boulainvilliers' thèse nobiliaire, although whether he had this in mind when writing is unclear:

'It is hardly possible to list all those many other conditions, internal no less than external, which may render him dependent and even oppressed: I am thinking of the innumerable obstacles that ignorance, clumsiness, rain, wind, fire and so on, may pose for his activity or his tranquility' (Sieyès 2014.b:145).

Sieyès intended to highlight the insufficiencies of an understanding of liberty as independence. Individuals were inescapably dependent on the external world, and this need not be seen as a hindrance. It was, rather, a form of empowerment. Sieyès asked the reader to consider an example: imagine two people caught in a thunderstorm. The first picks up a ladder and uses it to climb into the attic of a barn. The other in order to avoid dependency on the ladder, remains outside shivering and exposed in the thunderstorm' (Sieyès 2014.b:150). The former, empowered by the ladder, was able to pursue their will. The latter, in their desire to remain independent, could not.

Sieyès thought an asocial definition of liberty was impoverished. ${ }^{13}$ Liberty was enhanced by society just as the freedom of the will was enhanced by the sense organs, namely, via his characteristically expansive account of representation. Through the provision of public works, the quality of liberty was improved by augmenting the intellectual and physical powers on the sociable 
individual (2014.a:122). Sieyès understood social representation as a function of the division of labour, which he believed he had diagnosed some years earlier than Adam Smith and had taken considerably further (Sewell 1994:89). ${ }^{14}$ The division of labour included all aspects of productive society. Specialist labourers, in fulfilling duties that would otherwise fall on individuals, were said to be representatives. This model of representative labour was a fundamental indicator of freedom (Sieyès 2014.a:122). The act of entrusting others with tasks an individual was unable to complete effectively was an elementary feature of a society in which individuals were able to maximise their ability to act freely. Undertaking these duties oneself placed undue burdens that hindered the capacity for the individual to make free choices effectively. Sieyès's response was to encourage individuals to delegate those burdens to others, even if this required relinquishing control. Representation was a 'law of reciprocal commitment'; so long as all in society were committed to reciprocally representing others, acting through others allowed citizens 'to do as [they] want, to do it better, and... with as much ease if [they] did it [them]selves' (Sieyès 1999.c:460).

Sieyès was attending to the issue of commercial exchange, of which English commonwealthmen and their French adopters had shown suspicion. The individual was free in commercial society both because they were released from inconvenient tasks, thereby allotting free time, and because those inconvenient tasks would be completed to a higher standard. His intention was to demonstrate that, rather than supplanting virtue and liberty with private interests that were detrimental to the republic, commercial dependency would produce superior forms of liberty. Antiquated arguments of Frankish liberty were not only inflexible in their opposition to emergent social structures of commercial society; in their most malign forms, they were actively detrimental by entrenching the privileged order of the nobility. ${ }^{15}$ 


\section{REPUBLICAN LIBERTY AND THE THIRD ESTATE}

If dependency was critical to individual liberty, it was also, for Sieyès, central to the identity of the nation, and to assessing the condition of unfreedom that the Third Estate found itself in. This is significant insofar as Sieyès's conceptualisation of liberty was a crucial feature of his revolutionary pamphlets, and it allowed him to advance the cause of the Third Estate. Against both absolutism and its aristocratic republican opponents, he distinguished productive from pernicious forms of dependency, and designed a constitutionalism that celebrated the former and suppressed the latter.

As Sieyès understood it, dependency manifested as a 'vital force' [force vive] generated by representative labour. This was the political chemistry for social unification, and so it was 'general work' [travail général that was 'the foundation of society' (Sieyès 1999.b:176). The linguistic parallel with Rousseau was intentional, and with good reason. Representative labour was more capable of squaring individual liberty with collective identity without requiring anything so 'oppressive' as the civic education of the general will. ${ }^{16}$ Representative labour characterised the nation in accordance with his neologism 'adunation' (Sieyès 1789.a:18). In keeping with its obscure ecclesiastical origins, it was analogous to the way in which the apostles were united around Christ to form the Church, and yet remained apostles in their own right (de Baecque 1996:97). This ensured that one remained an individual within the political community.

This form of gesellschaft politics also allowed Sieyès to draw further distinctions between the three estates, and between the modes of dependency that governed these relations. What is the Third Estate? was prepared in the midst of the French public debt crisis which stretched the conventional political language of eighteenth-century French politics to its limits. Sieyès feared that the landowning First and Second Estates would choose to declare state bankruptcy in the face of this debt, thereby depriving creditors, primarily commoners in the Third Estate, of their return, while allowing the King's ministry financial autonomy once more (Sonenscher 1997). Sieyès's constitutional theory sought 
to disentangle decision-making from the estate structure of the ancien regime that would allow this. His adaptation of republican liberty was central to this enterprise, and to the identity of the nation that emerged from it.

In the first chapter of What is the Third Estate?, Sieyès discussed at length a sociological definition of the nation. Drawing on his understanding of representative labour, Sieyès argued that the nation consisted of a self-sufficient network of commercial exchange that sought to satisfy the needs of the individuals therein (Sieyès 2003.c:94-95). This is because the mechanisms of commercial representation served as a means to hold otherwise unsociable individuals together in political union with one another (Hont 2005:476). Sieyès argued that these commercial functions were undertaken by the Third Estate, and that the Third Estate alone contained 'everything needed to form a complete nation' (Sieyès 2003.c:95-6). Some have argued that this entailed an 'autodialecticalisation' of nationhood, whereby the revolutionary event actualised the potential nation embodied by the Third Estate (Foucault 2003:222; Mandelbaum 2016). This interpretation has Sieyès backward, reading Sieyès through the revolutionary spirit of the Jacobins. Sieyès explicitly rejected this sort of ruptural transformation that would be felt were France to declare bankruptcy. Sieyès carved a reformist path that preserved the French debt and attributed it to the nation (Sieyès 2003.a:64-67). To do so, Sieyès applied his language of commercial dependency in order to think through the political reordering of the French nation. In untangling the expressions of dependency in pre-revolutionary France, Sieyès emphasised the detriment of the legalised inequality of the ancien regime and argued for an alternative to the estate structure.

The dependency generated by representative labour was liberating insofar as it freed the individual from the time-consuming fulfilment of biological necessities and allowed them to divert time elsewhere. However, this required reciprocity, and only the Third Estate were committed to this. The First and Second Estates acted otherwise. The noble order, as Sieyès understood it, played no essential role in this commercial exchange economy. Their 
performance of public services was nothing more than an 'illusion', and their status was defined by 'idleness' (Sieyès 2003.c:96-97). They had no part in the organisation of the nation; they were 'a class of men who, having no function or any utility, nonetheless enjoy the privileges attached to their persons simply by dint of their existence' (Sieyès 2003.c:97, fn.5). The noble order was a 'burden' upon the nation. The clergy was different, still. The clergy was a representative profession, providing a service directly to individuals. While they were embedded in an economy of exchange, due to historical reasons they mistakenly assumed themselves to be a distinct order, rather than only a profession, and they bestowed upon themselves a privileged status (Sieyès 2003.c:96, fn.4).

The variegated language of dependency that Sieyès sought to identify had been flattened and degraded in ordinary language as the nobility had 'so loudly claim[ed the language of dependency and subordination] for themselves'. Sieyès dismissed the fiction of the thèse nobiliaire spread by the nobility that contended that their subordination to and dependence upon the will of the government was unjust (Sieyès 2003.b:82, fn.7). Sieyès saw that the opposition between governors and governed formed a 'true hierarchy', necessary to society, whereas subordination among the ranks of the governed was what he took to be a 'false, useless and odious' hierarchy (Sieyès 2003.b:82, fn.7). Sieyès was intent to parse this language in a more careful way in his revolutionary pamphlets. Here, he distinguished institutional forms of dependency from commercial variants of symbiotic and parasitic dependency.

The reciprocal commitments of commercial society produced a symbiotic mode of dependency. This was 'not subordination, but continual exchange' (2003.b:82). Because all citizens reciprocally relinquished the autonomy of their will in exchange to represent another's, Sieyès did not believe that there was a pernicious effect, so long as commitments were countervailed. This did not amount to a mechanism of oversight; it was a form of trust on the knowledge that a representative would cede control to another within a different area of competence. Perniciousness did follow from the dependency borne by 
the noble order. In placing themselves outside the relations of reciprocal exchange, the nobility, Sieyès argued, were a 'people apart'. They were:

'a false people that, not being able to exist by itself, since it has no functioning organs, attaches itself to a real nation like one of those parasitic forms of vegetation that live off the sap of the plants that they exhaust and desiccate' (Sieyès 2003.c:97, fn.5).

The nobility were parasitic dependents. This was not the dependency of a slave upon the will of a master, but the dependency of the idle on the economically productive. While Sieyès did not expressly use the term 'dependency' to capture this relationship, the contrast he drew with the reciprocal dependency of commercial exchange was plain to see. The nobility enjoyed the commerce of the nation while violating the principle of reciprocity that underwrote it.

This alone only emphasised that the nobility was a fetter upon the productivity of the nation, which, while pernicious and exploitative, did not highlight a relationship of domination or subordination in either direction. The connection between dependency and domination coalesced when the political prerogatives of the privileged order were enacted. Here, Sieyès did employ the vocabulary of dependency in line with conventional use by the nobility. However, armed also with his account of commercial dependency, he did so with the express intention of challenging the thèse nobiliaire, and the mixed constitution more generally, which sought to 'balance' the interests of the competing orders. When discussing the Estates-General, Sieyès emphasised that the institution was to be 'master of the decision', and that 'no kind of dependency can be allowed to be felt' (Sieyès 2003.a:23). The Estates-General's legitimacy was closely tied to the autonomy of the nation's will, or at least the representation of that will through the pouvoir commettant. What was illegitimate was the domination of the nation's will by the privileged, factional interests of the First and Second Estates. This manifested in an acute way among the rural poor. Sieyès recognised the enterprise of the nobility was to maintain their idleness while turning the rural peasantry against the Third Estate. The nobility, 
in clinging to the remnants of feudalism, had successfully ensured the rural workers were left 'living in dependence on the aristocracy', and that this dependency ensured a 'coalition' between the lowest class in society and the privileged orders (Sieyès 2003.a:108, fn.14). The consequence of this material dependence was to extend the political influence of the seigneurial landowners into the Third Estate by way of dominating the rural peasantry. It was on this basis that Sieyès advocated necessary measures to counteract this influence. The first had been to exclude those in positions of dependency from acting as representatives, while also restricting the freedom of members of the Third Estate from electing nobles or clerics as their representatives (Sieyès 2003.c:107110). These were necessary, if unfortunate, courses of action in order to ensure that the commons' confidence would not be usurped by the will of the noble order, and were necessary only until citizens could be removed from the dependency of the nobility and could be judged 'eminently fit' to uphold the nation's interest (Sieyès 2003.c:109).

Sieyès saw that the old feudal forms of dependency had not fallen away with the advent of commercial dependency. Instead, commercial society gave a new form to the parasitic dependency of the noble order, now dependent on the urban workers of the Third Estate. For Sieyès, commercial dependency, in either of its symbiotic or parasitic variants, was crucially different from feudal dependency insofar as they enhanced the freedom of one or both parties, rather than curtail it. However, so long as the parasitic dependency of the nobility persisted, it would prevent the withering away of the First Estate, and so feudal dependency was able to contaminate the political system. Domination arose through the remnants of the feudal system, and so in order to prevent domination, political representation needed to be severed from the estate structure of the old regime. ${ }^{17}$ This had been the basis upon which Sieyès had endorsed the geometric redrawing of the administrative cartography of France (Sieyès 1789.a). Antoine de Baecque has argued that this intended to disrupt the 'ancestral customs' and 'ethnic personalities' of the French provinces (de 
Baecque 1996:114). While it was Sieyès's intention to dull the provincial esprits de corps in order to forge a French Nation, this was because he saw domination, in the form of feudal dependency, at the root of the old provincial system. Sieyès was clear that seigneurial offices and the bailliage system were used to conceal 'imperious domination', and that their removal was key to the recovery of liberty in the provinces most removed from Paris (Sieyès 2003.c:107; see also 2003.a:37). The geometric departments sought to do that by supplanting the traditional structures of domination in the provinces.

If symbiotic commercial dependency was to supplant the dependency of the old regime, Sieyès believed it possible, even, to square representation with monarchy. This had been at the root of Sieyès's disagreement with Thomas Paine. For Paine, monarchy was antithetical to both republicanism and representation insofar as it was premised upon the will of an individual (2003:165). This was because Paine understood liberty exhaustively in accordance with the commonwealth tradition, in which monarchy amounted to nothing more than 'arbitrary power in an individual person; in the exercise of which, bimself, and not the res-publica, is the object' (Paine 1994:146). ${ }^{18}$ Sieyès opposed this premise, and rejected the connection Paine presupposed between republicanism and representation. This was a category error: while 'representatives' were to be distinguished from 'masters', it did not follow that all republican governments were representative, nor that all monarchs were masters (Sieyès 2003.d:168-9). Rather, Sieyès understood representation and mastery to be attached to the two modes of commercial and feudal dependency respectively, and that the two forms of government might be modelled on either, depending upon the underlying social arrangements. The first priority, for Sieyès, was to address the socio-economic relations that enabled or frustrated freedom, and then institutional arrangements would fall in line. Within an appropriately representative political system, which was nothing more than an extension of representative labour, the monarch was not a master, but executor of the will of the nation. 
While the monarch was the point of an 'individual decision', their power was tempered by the constituent and constituted powers. Sieyès referred to this as a 'triangle Monarchy', which was the 'true bulwark of public liberty' (Sieyès 2003.d:171). Tuck (2016:175) has argued that this amounted to a separation of powers. This point requires qualification. While Sieyès had been keen to avoid the language of sovereignty (Rubinelli 2019.a), he did not default to the separation of powers as his alternative. Sieyès was dissatisfied with how a republican separation of powers was able to adequately address the issue of domination in France. Through the separation of powers, it was possible to maintain the estate structure and the feudal dependency that came with it. Moreover, constitutions that were premised upon this system of counterweights were precarious; they did not presuppose social unity in anything more than a system of property rights and this meant that none of the various bodies granted fullness of power need plausibly claim to represent the nation (Sieyès 2014.c:15457). Accordingly, Sieyès did not see his 'triangle monarchy' as a separation of powers in the conventional sense. Rather, Sieyèsian constitutionalism was premised on the 'organised unity' of 'ascending... and descending actions' between the nation and its representatives. This granted specific areas of competence to the respective representative organs of the nation, and through which they were expected to cooperate, rather than serve as competing counterweights (Sieyès 2014.c:154; Rubinelli 2019.b). When ordered this way, the constitution tempered the plenitude of power so to avoid what Sieyès referred to as a 'ré-totale' (Sieyès 2014.c:156), while also ensuring that the estate structure was dissolved so to prevent domination by the noble order.

This also amounted to a reworking of citizenship, when compared to commonwealth-inspired arguments that emphasised the role of the landed nobility (Boulainvilliers 1727:50). The point was more important to Sieyès than is ordinarily appreciated. Manin (1997:3) argues that representation was needed as citizens no longer enjoyed the leisure to participate in public affairs. This marginalises the corollary reasoning that Sieyès emphasised, namely, that he was 
characteristically dissatisfied with a model of citizenship that granted privileges to the economically idle at the cost of the productive, and so he expressly rejected the idea that one's economic independence was a sufficient marker of citizenship. It was not enough that one was a free person. Rather, those Sieyès termed 'active' citizens were 'stakeholder[s] in the great business of society' (Sieyès 2014.a:127). ${ }^{19}$ While property was a necessary condition of citizenship, for Sieyès, it was not a sufficient one to indicate a stake in society. ${ }^{20}$ Those who did have the leisure time that would ordinarily allow them to participate in politics should be excluded if that leisure was the result of their parasitic dependence on the labour of others. This applied to all economically idle from the nobility to beggars and vagabonds (Sieyès 2003.c:107).

\section{PetTIt, Sieyès ANd CONSTITUENT Power}

In On the People's Terms, Pettit (2012:285-292) appeals to the Sieyèsian notion of constituent power on the understanding that it can be incorporated into his version of republican constitutionalism. Until now, I have sought to delineate Sieyès's commercial republicanism, and to demonstrate that one target was a version of aristocratic French republicanism that drew on the English commonwealth tradition. In what remains of this paper, I argue that this diverges in a fine but significant way from Pettit's formulation of republicanism: while Pettit appreciates the importance of trust and mutual dependence to public life, he relies on a mechanism of public responsiveness in order to keep this in check. Sieyès's representative labour does not rely on this mechanism of public responsiveness; it was designed to release individuals from the need to vigilantly ensure their interests were being tracked. This was a key feature of his account of constituent power, which sought to disentangle the decision-making of the nation from the individuals who composed it.

Pettit's republicanism does not, of course, endorse what Sieyès described as 'liberty of independence'. Pettit argues that non-domination is compatible with mutual dependence so long as interests are appropriately tracked. A 
constitutionalism of non-domination is maintained through 'republican civility'. One component of this is an ethos of vigilance to ensure lawmaking remains non-arbitrary (Pettit 1997:249-250). He is clear, however, that this is compatible with mechanisms of trust. Vigilance does not equate to the refusal of trust; if this were so, the condition of eternal vigilance would force citizens to forgo the liberty they seek to maintain. Vigilance is a form of 'expressive' distrust. The performance of trust and distrust is distinct from the implicit feeling of trust that one my hold of a fellow citizen or institution. There is no tension in possessing implicit trust, while performing expressive distrust. Pettit's recommendation is that 'whatever confidence people fee in the authorities, they will have all the more reason to feel such confidence if they always insist on the authorities going through the required hoops in order to prove themselves virtuous' (Pettit 1997:264). The performance of vigilance, for Pettit, is a necessary condition upon which trust can be underwritten, insofar as it provides a necessary safetycheck within an exchange economy.

Sieyès's constitutionalism differed on this fine point. Sieyès understood a well-ordered society to involve a trade-off between competing conceptions of liberty, and the prevention of domination was to be balanced against the condition of empowerment. Accordingly, if the gains of liberty were sufficiently justified, a mechanism for vigilance may readily give way (Sieyès 1999.c:477; 2014.b:149). ${ }^{21}$ Under the system of representative labour, the gains to liberty from the delegation of tasks to artisans and experts were significant, and so the threshold at which vigilance was required to police their actions was considerably higher. In practice, this had important implications for the representative system that he designed. Political representation was an extension of representative labour. Sieyès was satisfied for constitution-writing to be entrusted to professional representatives as this disentangled the individual from politics ad ensured a constitution that was not the product of the whim of the multitude of politically disinterested individuals who comprised the nation (see Sonenscher 
2003:xvii-xxii). Political representatives were experts charged with forming, rather than communicating the will of the nation. He wrote:

'any nation which is able to form a common will by means of representatives invested with authenticated powers is able to exercise the full extent of the legislative power' (Sieyès 2003.a:13).

Sieyès, of course, mitigated against the most ruinous forms of domination by excluding from representative offices both the nobility and the rural peasants dependent upon the nobility. Nevertheless, he expressly rejected theories of delegation that presupposed vigilant oversight of a representative's actions. He took these to be 'essentially vicious'; those 'obliged to adhere scrupulously to the commission of those who mandate them' were always at odds with establishing a common will (Sieyès 2003.a:11). Such politics would inevitably return to the estates and provinces of the ancien régime, for power would cease to emanate from the whole but have its origins in the respective constituencies.

The difference between Pettit and Sieyès is rooted in the normative orientation that shapes how a will emanates from the nation. For Pettit nondomination runs through each step of his argument, and so his preferred mode of representation is guided by 'responsiveness', whereby the people's disposition has priority over the representatives', and a contestatory public square provides the landscape from which representative draw their positions (Pettit 2012:19799). This was not so for Sieyès. While representatives were elected, they were not necessarily guided by the disposition of the nation, or any particular constituents within it, but were to 'form' that disposition. While more substantive than the sort of fictional attribution endorsed by Hobbes, it does not meet the threshold of responsiveness prescribed by Pettit. This was because Sieyès prioritised a mode of liberty that sought to release individuals from otherwise burdensome tasks.

This was important to the Sieyèsian notion of constituent power, too. As Pettit presents it, constituent power features as a component within a 'dualaspect' model of democracy. In determining the metaprinciples to guide 
lawmaking, constituent power would serve as the mechanism of vigilance through which the people could assess from critical distance the internal function of constitutional decision-making, thus serving as guardians of liberty (Pettit 2012:290). ${ }^{22}$ Sieyès' intention had not primarily been to provide a mechanism of critical oversight. Rather, his formulation of constituent power, like his account of representation, sought to ensure the political process proclaimed the interest of the nation without allowing the individuals comprising the nation from becoming entangled with politics. This was because Sieyès held a considerable distrust toward democracy (Quiviger 2008:238). The distinction between constituent and constituted powers was intended to temper the plenitude of power not by checking it with an equivalent power but by allocating the nation only the task of authorising the constitution. This intended to prevent the ordinary legislature from modifying the constitution, so forcing it to work within fixed parameters. However, this was a distinction that cut both ways: the constituent power had no part to play in ordinary law-making. Constituent and constituted powers were compartmentalised within particular spaces of competence. This is clearest in Sieyès' rejection of the amendment procedure which would complicate the rigid distinction between constituent and constituted powers, in favour of a new constituent assembly (Sieyès 1789.b). Moreover, the people were restricted only to the ex ante selection of extraordinary representatives, exercising the pouvoir commettant (Sieyès 1789.c:36). Thus, while the nation was the nominal bearer of constituent power, it was to be executed by the extraordinary representatives. ${ }^{23}$ This was evident in Sieyès's decisive rejection of the imperative mandate that would subject representatives in the constituent assembly to public scrutiny (see Rubinelli 2019.a:59). Representation served as the exemplary tool to vocalise the nation's will in such a way that representatives could act in the name of the constituent power whilst allowing the individual citizens of the French nation to live according to their free choice. Though a national will was necessary, its expression was not to come at the cost of individual non-political liberty. 
The restrictions that he placed on the operation of the constituent power intended to achieve a precise goal: to remove individuals from the political sphere as soon as it became viable. This had two aspects. First, in serving the general framework of liberty that he had constructed, the delegation of constitution-writing to superior representatives was suitable among a population that had neither the education nor time to complete these tasks themselves. Doing so would enhance the freedom of choice among citizens engaged in nonpolitical life. Second, this constitutional structure intended to attenuate the expressive distrust and political participation that, if it came to dominate, may produce a 'ré-totale' (Sieyès 2014.c:156).

The precise ordering of this did change for Sieyès throughout the revolution. In the early years of the revolution, Sieyès did not think that vigilant guardianship was necessary. A well-designed constitution would be enough, and social relations would settle accordingly (Pasquino 2008:23). From 1795, Sieyès became more inclined to frame his argument for constituent power in the language of guardianship, professing the place of a 'constitutional jury' to safeguard the constitution (Sieyès 2014.c:159). This was, for Sieyès, a recalibration of constituent power in light of what he took to be its misappropriations during the Terror. Nevertheless, this retained the presumption of professional representatives, and a constitutional structure that kept active civic participation to a minimum (Goldoni 2012:231-232).

This should be understood as a problem for Pettit's account of republicanism. While Pettit recognises the merits of mutual dependence within an exchange economy and a political system premised upon this, Pettit also understands the notion of constituent power to serve as a mechanism of responsive vigilance against the forms of domination and usurpation that may follow from unscrutinised trust. Sieyès did not intend constituent power to operate in this way; rather, constituent power was an extension of the logic of representative labour that, for Sieyès, defined the nation, and this intended to disentangle ordinary citizens from political commitments. While Sieyèsian 
constitutionalism embedded a foundational set of constrains over legislative action, Sieyès expected citizens to place their trust in representatives without recourse to the performative mechanisms of vigilance that Pettit recognises as a necessary guard.

\section{CONCLUSION}

The late $18^{\text {th }}$ and $19^{\text {th }}$ centuries were a crossroads for republicanism. Recent work has successfully excavated a set of 'radical' paths that republicanism took in this period (Gourevitch 2015; Leipold et al. 2020; Muldoon 2019). Republicanism fragmented in various directions, though, and this 'radical' genealogy should not delink republicanism from its liberal descendants. Many of the contributions of Sieyès's constitutional theory would, in the following decades, be incorporated into the inchoate French liberalism, not least through Benjamin Constant. Even if, as Pasquino (1998) argues, Sieyès gave birth to modern liberal constitutionalism, Sieyès self-identified as a republican. Part of this paper has been an attempt to understand what Sieyès understood by that.

Sieyès understood his republicanism to hang on an account of liberty that celebrated the advantages gained through reciprocal exchange. Sieyès developed this account of liberty in contrast with the 'Frankish liberty' of the thése nobiliare. These arguments had defended the order of nobles as guardians of Frankish liberty against monarchical absolutism. While Sieyès opposed absolutism, he rejected also the justifications that maintained the privileges of the noble order. His conceptualisation of liberty through representative labour allowed both to identify the collective identity of the Third Estate as a relation of symbiotic commercial dependency, and to distinguish cases of collective injustice, namely, the domination of the Third Estate by the privileged order within the Estates General, and the structural conditions that allowed the nobility to survive, parasitically dependent on the labour of the Third Estate. In doing so, however, Sieyès side-lined the arguments of civic vigilance that had been employed to justify the unique status of the nobility. 
Pettit has maintained that his analytical arguments should stand independently from his historical excavation of a lost republicanism. My argument has intended to confront both components of this claim by drawing on the work of a figure Pettit has invoked for his cause. Historically, the case of Sieyès provides further evidence against the coherence of a republican tradition of 'non-domination'. Analytically, too, this is significant as the side-lining of vigilance should be seen as a conceptual problem for Pettit's brand of responsive republicanism because Sieyès allows for a considerably higher threshold where political decisions can go untracked. Pettit's interpretation of constituent power loses sight of the fundamental aims of Sieyès: the nation, as the abstract bearer of French debt, was to be the nominal authoriser of the constitution, but this was not intended to burden the citizens who composed it. Citizens were not to stand guardian over the constitution but were to release these tasks to professional representatives, so they might act on their non-political freedom. 


\section{NOTES}

1 Quentin Skinner's favoured language for assessing republican liberty is the notion of 'dependency' (1998:46; 2002:247). While preferring the language of domination, Pettit has accepted these terms to be interchangeable (2002:341).

2 Pettit has recognised the stylised nature of his reading of these traditions but maintains that he does 'no serious injustice' to the figures he addresses (2013:169).

3 This tendency persists among contemporary theorists of constituent power. See Kalyvas (2013:227).

4 Recent French scholarship has placed a critical gloss on this thesis, arguing that the preservation of liberty takes the form of an 'authoritarian liberalism' (Sommerer 2017), or a 'conservative republicanism' (Ayad-Bergounioux 2014). This is closely related to the position that I develop in this paper. On Sieyès's 'authoritarian' preservation of liberty in the English literature, see Jainchill (2008: 197-241). A prominent exception among the contemporary French literature is Furet (1992:45-51) whose emphasis has not been on Sieyès's liberalism, but on the radicalism of building a unity of the French nation against the privileged order.

5 There is some precedent for this view, see Sieyès (2003.b:70). Daphne Trevor (1935:341342 ) advances an analogous reading of negative liberty in her contractarian interpretation of Sieyès.

6 Sieyès's account of deliberation in the National Assembly is mentioned in passing in Pettit (1997:189), while the incorporation of constituent power into republican constitutionalism is briefly outlined in Pettit (2012:285-92).

7 All translations from French are my own.

8 There is early work declaring the influence of Harrington on Sieyès. See Clapham (1912:24); Trevor (1935). While Sieyès showed familiarity with Harrington from as early as 1770 , his direct influence appears to be limited to his constitutional writings after 1795, when Harrington had been translated into French.

9 Sonenscher recognises Sieyès's familiarity with Boulainvilliers in his editorial notes (Sieyès 2003.b:177, \$99). See also Chaussinard-Nogaret (1985:18-20). Sieyès listed numerous texts of Boulainvilliers' in his private bibliographies (2007.a: 282-83). The two figures form a major thesis within Foucault's Society Must Be Defended, each representing distinctive transformations in discursive fields of nationhood (Foucault 2003:140-238) On Sieyès general challenge to the thèse nobiliaire, see Rosanvallon (2011:12-15).

10 On Boulainvilliers' status as an idiosyncratic republican, and the influence of the English Commonwealth tradition, see Wright (2002:290-292), and Hammersley (2010:64-69).

11 For assessments of Mably's Des Droits, see Baker (1990:88-92), Wright (1997:70-80) and Hammersley (2010:89-91). An early biographer of Sieyès, Albéric Néton (1900:118), argued that Sieyès was an 'ardent popularist' of Mably. Forsyth $(1987: 41,65)$ has identified several works of Mably's catalogued by Sieyès, though remains unconvinced that he marks out a special influence.

12 Most notably Jean-Jacques Rousseau (1997:114). See especially Douglass (2013).

13 I distinguish between 'social' and 'asocial' forms of liberty as, pace Urbinati (2006:146), Sieyès was not drawing a distinction between positive and negative liberty, but between two variations of negative liberty. Both evacuated the individual of obstacles that inhibit exercise of the will, though they do so differently. The former isolated the individual from obligation 
to others, whilst the later delegated responsibilities. They each result in greater space for individual choice, though the latter is more successful on Sieyès's account. The positively framed 'liberty of the ancients' was excluded entirely.

14 While their conclusions may have been developed independently from one another, it remains an open question whether Sieyès did diagnose this earlier, or whether he took it further. Smith had begun work on Wealth of Nations considerably earlier than the 1770 date that Sieyès claims to have made his diagnosis, while covering much of the ground of Sieyès in book III, chapter IV (Smith 1904:381-394).

15 Sieyès expressed this in What is the Third Estate?, after an extended discussion of the thèse nobiliaire: 'Why should not reason and justice, which may one day be motives as strong as vanity, press the ranks of the privileged, moved by a new, more true, and more social interest to seek their rebabilitation within the order of the Third Estate?' (Sieyès 2003.b:99).

16 For Sieyès's characterisation of the general will as oppressive, see his discussion of a 'ré-totale' in Sieyès (2014.c:156). On the implicit contrast between the ré-totale and the republique, see Sonenscher (2003:xxi).

17 Sieyès, here, was making a doubly anti-Rousseauvian point. Not only did he seek to celebrate, and not admonish, representation, he also sought to show that, pace Rousseau (1997:114), representation did not arise from feudalism.

18 Pettit (1997:56) has cited precisely this passage from Rights of Man in order to develop his understanding of liberty as non-domination. On Paine's position toward Sieyès, see Hobson (2008:456-460).

19 Sieyès's distinction between passive and active citizenship amounted to the distinction between the protection of one's person and one's property, and the right to play an active role in political life (Sieyès 2014.a:127).

20 In addition to his notion of 'active' citizenship, Sieyès maintained two further stipulations on suffrage, namely property-ownership and tax contributions. Property ownership was necessary in order to ensure voters were not financially dependent on others (see Sieyès 1789.c:32-33). This was analogous to the measures Sieyès implemented to address the dependence of the rural poor on seigneurial landowners Tax contributions endeavoured to ensure that the electorate held a stake in society in accordance with his propositions of active citizenship (Sieyès 2007.b:457-460)

21 In On the People's Terms, Pettit distinguishes between 'invasive' and 'vitiating' hindrances. Vitiating hindrances are those patterns in society that reduce one's choice; invasive hindrances are actions that subject one to the will of another thereby denying one the chance to choose. Pettit (2012:40) illustrates this with the examples of denying one the option of reading the newspaper, thereby invading one's choice, and print newspapers falling out of circulation following the uptake of electronic news sources, thereby vitiating one's choice. Invasive hindrances are pernicious insofar as they are arbitrary and intended invasions of one's liberty. The same agential responsibility cannot be attached to 'vitiating' hindrances. While not insignificant, Pettit takes vitiating hindrances to be secondary to invasive hindrances (Pettit 2012:44). Sieyès did not think vitiating hindrances should be treated as secondary. Poorly organised social relations could produce vitiating hindrances that were equally damaging as invasive hindrances. While commercial society may lead to invasion in some areas, it could enhance the choices available to citizens and thus guard against vitiating hindrances. This trade-off was an appropriate one (Sieyès 1999.c:460; 2014.b:148-49). 
Forthcoming in European Journal of Political Theory

22 This approximates, but is not identical with, early modern resistance theories of constituent power (see Lee 2016; Lindsay 2019).

23 Rubinelli (2019.a:54) argues that the pouvoir constituant and pouvoir commettant should not be confused, as they illustrate distinctive forms of power. That the constituent power is to be exercised through an $e x$ ante delegation of a pouvoir commettant, indicates that this distinction was only a nominal one. This allowed the constitution to be attributed to the authority of the nation while the delegates would exercise the real task of constructing constitutional norms. Sieyès was against the notion of a ratification mechanism, and on this point he was out of sync with many contemporaries (Tuck 2016:168). 


\section{REFERENCES}

Arendt H (1967) The Origins of Totalitarianism. New York: Harcourt.

Ayad-Bergounioux S (2014) De Brumaire à la formation de l'État bureaucratique consulaire: le rôle des républicains conservateurs. Annales Historiques de la Révolution Française 378:51-72.

Baczko B (1988) The Social Contract of the French: Sieyès and Rousseau. The Journal of Modern History 60(S.1):98-125.

Baker KM (1990) Inventing the French Revolution: Essays on French Political Culture in the Eighteenth Century. Cambridge: Cambridge University Press.

Boulainvilliers H (1727) Histoire de l'Ancien Gouvernement de la France, Tome I. Amsterdam.

Carré de Malberg R (1922) Contribution à la théorie générale de l'Etat. Paris: Dalloz.

Chaussinand-Nogaret G (1985) The French Nobility in the Eighteenth Century: From Feudalism to Enligbtenment. Cambridge: Cambridge University Press.

Clapham JH (1912) The Abbé Sieyès: An Essay in the Politics of the French Revolution. London: King.

Clavreul C (1987) Sieyès et la Genèse de la Representation Moderne. Droits: Revue Franc aise de Théorie Juridique 6:47-66.

de Baecque A (1996) The Body Politic: Corporeal Metaphor in Revolutionary France, 1770-1800. Stanford: Stanford University Press.

Douglass R (2013) Rousseau's Critique of Representative Sovereignty: Principled or Pragmatic? American Journal of Political Science 57(3):735747.

Fauré C (2008) Sieyès, Rousseau et la théorie du contrat. In: Quiviger P-Y (ed) Figures de Sieyès. Paris: Sorbonne.

Forsyth M (1987) Reason and Revolution: The Political Thought of the Abbé Sieyès. Leicester: Leicester University Press.

Foucault M (2003) Society Must Be Defended: Lectures at the College de France, 197576. London: Penguin.

Furet F (1992) The French Revolution, 1770-1814. Oxford: Blackwell.

Furet F and Ozouf M (1993) La Siècle da l'avènment républicain. Paris: Gallimard.

Ghosh E (2008) From Republican to Liberal Liberty. History of Political Thought 29(1):132-166.

Goldini M (2012) At the Origins of Constitutional Review: Sieyès' Constitutional Jury and the Taming of the Constituent Power. Oxford Journal of Legal Studies 32(2):221-234. 
Gourevitch A (2015) From Slavery to the Cooperative Commonwealth: Labour and Republican Liberty in the Nineteenth Century. Cambridge: Cambridge University Press.

Guilhaumou J (2006) Sieyès et le non-dit de la sociologie: du mot à la chose. Revue d'Histoire des Sciences Humaines 15(2):117-134.

Guilhaumou J (1997) Nation, individu et société chez Sieyès. Genèses 26:4-24.

Hammersley R (2010) The English Republican Tradition and Eighteenth Century France. Manchester: Manchester University Press.

Hobson C (2008) Revolution, Representation and the Foundations of Modern Democracy. European Journal of Political Theory 7(4):449-471.

Hont I (2005) Jealousy of Trade: International Competition and the Nation-State in Historical Perspective. Cambridge: Harvard University Press.

Jainchill A (2008) Reimagining Politics after the Terror. London: Cornell University Press.

Kalyvas A (2013) Constituent Power. Political Concepts: A Critical Lexicon 3(1).

Lee D (2016) Popular Sovereignty in Early Modern Constitutional Thought. Oxford: Oxford University Press.

Leipold B, Nabulsi K and White J (2020) Radical Republicanism: Recovering the Tradition's Popular Heritage. Oxford: Oxford University Press.

Lindsay A (2019) "Pretenders of a Vile and Unmanly Disposition": Thomas Hobbes on the Fiction of Constituent Power. Political Theory 47(4): 475-499.

Mably G (1972) Des Droits et Des Devoirs du Citoyen. Paris: Marcel Didier.

Mandelbaum M (2016) The Fantasy of Congruency: The Abbé Sieyès and the 'Nation-State' Problématique Revisited. Philosophy and Social Criticism 42(3):246-266.

Manin B (1997) The Principles of Representative Government. Cambridge: Cambridge University Press.

McCormick JP (2003) Machiavelli Against Republicanism: On the Cambridge School's "Guicciardinian Moments". Political Theory 31(5):615-643.

Muldoon J (2019, Forthcoming) A Socialist Republican Theory of Government. European Journal of Political Theory. 1-21. DOI: $10.1177 / 1474885119847606$

Negri A (1999) Insurgencies: Constituent Power and the Modern State. Minneapolis: University of Minnesota Press.

Nelson E (2004) The Greek Tradition in Republican Thought. Cambridge:

Cambridge University Press. 
Néton A (1900) Sieyes (1748-1836), d'après des documents inédit. Paris: Perrin.

Nicolet C (1982) L'Idée Républicaine en France. Paris: Gallimard.

Paine T (1994) Rights of Man. In: Foot M (ed) Rights of Man \& Common Sense. London: Everyman.

Paine T (2003) From Mr Thomas Paine to M. Emmanuel Syeyes. Paris, 8 July 1791. In: Sonenscher M (ed) Political Writings. Indianapolis: Hackett, pp.165-166.

Pasquino P (1987) Emmanuel Sieyès, Benjamin Constant et la Gouvernement des Moderns: Contribution a l'histoire du concept de representation politique. Revue Française de Science Politique 37(2):214-229.

Pasquino P (1998) Sieyes et l'invention de la constitution en France. Paris: Odile Jacob.

Pasquino P (2008) Constitution et pouvoir constituant: le double corps du peuple. In: Quiviger P-Y, Denis V and Salem J (eds) Figures de Sieyès. Paris: Sorbonne, pp.13-23.

Pettit P (1997) Republicanism: A Theory of Freedom and Government. Oxford: Oxford University Press.

Pettit P (2002) Keeping Republican Freedom Simple: On a Difference with Quentin Skinner. Political Theory 30(3): 339-356.

Pettit P (2012) On The People's Terms: A Republican Theory and Model of Democracy. Cambridge: Cambridge University Press.

Pettit P (2013) Two Republican Tradition. In: Niedernerger A and Schink P (eds) Republican Democracy: Liberty, Law and Politics. Edinburgh: Edinburgh University Press, pp.169-204.

Philp M (1998) English Republicanism in the 1790s. Journal of Political Philosophy 6(3):235-262.

Quiviger P-Y (2008) Sieyès et Spinoza. In: Quiviger P-Y (ed) Figures de Sieyès. Paris: Sorbonne, pp.227-239.

Rosanvallon P (2011) The Society of Equals. Cambridge: Harvard University Press.

Rousseau JJ (1997) The Social Contract and Other Later Political Writings. Cambridge: Cambridge University Press.

Rubinelli L (2019.a) How to Think Beyond Sovereignty: On Sieyes and Constituent Power. European Journal of Political Theory 18(1):47-67.

Rubinelli L (2019.b) Sieyes versus Bicameralism. Review of Politics 81(2):255-279.

Schmitt C (2008) Constitutional Theory. Durham: Duke University Press.

Sewell WH (1994) A Rhetoric of Bourgeois Revolution: The Abbé Sieyes and What is the Third Estate? Durham: Duke University Press. 
Sieyès EJ (1789.a) Observations sur le Rapport du Comite de Constitution, Concernant la Nouvelle Organisation de la France. Versailles: Baudouin.

Sieyès EJ (1789.b) Dire de l'abbé Sieyès, sur la question du Veto royal. Versailles: Baudoin.

Sieyès EJ (1789.c) Préliminaire de la Constitution Françoise: Reconnoisance et Exposition Raisonnée des Droit de l'Homme \& du Citoyen. Paris: Baudoin.

Sieyès EJ (1999.a) Le Grand Cahier Métaphysique. In: Fauré C (ed) Des Manuscrits de Sieyès, 1773-1799. Paris: Honoré, pp.47-166.

Sieyès EJ (1999.b) Lettres aux économistes sur leur système de politique et de morale. In: Fauré C (ed) Des Manuscrits de Sieyès, 1773-1799. Paris: Honoré, pp.167-192.

Sieyès EJ (1999.c) Fragments Politique. In: Fauré C (ed) Des Manuscrits de Sieyès, 1773-1799. Paris: Honoré, pp.441-494.

Sieyès EJ (2003.a) Views of the Executive Means, which are at the Disposal of the representatives of France. In: Sonenscher M (ed) Political Writings. Indianapolis: Hackett, pp.1-67.

Sieyès EJ (2003.b) An Essay on Privilege. In: Sonenscher M (ed) Political Writings. Indianapolis: Hackett, pp.68-91.

Sieyès EJ (2003.c) What is the Third Estate? In: Sonenscher M (ed) Political Writings. Indianapolis: Hackett, pp.93-162.

Sieyès EJ (2003.d) The Explanatory Note of M. Syeyes, in Answer to the Letter of Mr. Paine. In: Sonenscher M (ed) Political Writings. Indianapolis: Hackett, pp.163-173.

Sieyès EJ (2007.a) Les Bibliographies de Sieyès. In: Fauré C (ed) Des Manuscrits de Sieyès. Paris: Honoré, pp.81-299.

Sieyès EJ (2007.b) Constitution Hypothétique. In: Fauré C (ed) Des Manuscrits de Sieyès, Tome II: 1770-1815. Paris: Honoré, pp.409-494.

Sieyès EJ (2014.a) Reasoned Exposition of the Rights of Man and Citizen. In: Lembcke OW and Weber F (eds) Emmanuel Joseph Sieyès: The Essential Political Writings. Leiden: Brill, pp.118-134.

Sieyès EJ (2014.b) Of the Gains of Liberty in Society and in the Representative System. In: Lembcke OW and Weber F (eds) Emmanuel Joseph Sieyès: The Essential Political Writings. Leiden: Brill.

Sieyès EJ (2014.c) Sieyès's Views Concerning Several Articles of Sections IV and V of the Draft Constitution. In: Lembcke OW and Weber F (eds) Emmanuel Joseph Sieyès: The Essential Political Writings. Leiden: Brill, pp.152-169. 
Skinner Q (1998) Liberty Before Liberalism. Cambridge: Cambridge University Press.

Skinner Q (2002) A Third Concept of Liberty. Proceedings of the Aristotelian Society 117:237-268.

Smith A (1904) An Inquiry into the Nature and Causes of the Wealth of Nations, Vol.1. London: Methuen.

Sommerer E (2017) Construire et défendre le libéralisme en période révolutionnaire: les justifications de la préservation illibérale de la liberté chez Sieyès. Cabiers d'économie Politique 73(2):151-179.

Sonenscher M (1997) The Nation's Debt and the Birth of the Modern Republic: The French Fiscal Deficit and the Politics of the Revolution of 1789, Part II. History of Political Thought 18(2):267-325.

Sonenscher M (2003) Introduction. In: Sonenscher M (ed) Political Writings. Indianapolis: Hackett.

Trevor D (1935) Some Sources of the Constitutional Theory of the Abbé Sieyès: Harrington and Spinoza. Politica 1(3):325-342.

Tuck R (2016) The Sleeping Sovereign: The Invention of Modern Democracy. Cambridge: Cambridge University Press.

Tyrsenko A (2000) L'Ordre Politique ches Sieyès an l'an III. Annales Historiques de la Révolution Française 319:27-45.

Urbinati N (2006) Representative Democracy: Principles and Genealogy. Chicago, IL: University of Chicago Press.

Wright JK (1997) A Classical Republican in Eighteenth Century France: The Political Thought of Mably. Stanford: Stanford University Press.

Wright JK (2002) The Idea of a Republican Constitution in Old Régime France. In: van Gelderen M and Skinner Q (eds) Republicanism, A Shared European Heritage, Vol. I: Republicanism and Constitutionalism in Early Modern Europe. Cambridge: Cambridge University Press.

Zweig E (1909) Die Lehre vom Pouvoir Constituant. Tübingen: J.C.B. Mohr. 